\title{
Question Forms, Conditionals, and Second-Person Pronouns Used by Adolescent Native Speakers across Two Levels of Formality in Written and Spoken French
}

\author{
ROY LYSTER \\ Department of Second Language Education \\ McGill University \\ 3700 McTavish Street \\ Montreal, Quebec \\ Canada H3A IY2 \\ Email: cxrl@musica.mcgill.ca
}

\begin{abstract}
In response to research recommending a more explicit focus on sociostylistic variation in immersion classrooms, this study presents written data from a sample of 81 adolescent native speakers of French in the Quebec City area and oral data from a subsample of 44. Sociostylistic features were examined in formal letters and informal notes written by the native speakers as well as in utterances produced in a series of simulated formal and informal contexts involving the speech acts of requesting, complaining, and offering assistance. The article first describes weaknesses in the sociolinguistic competence of second language (L2) learners as documented by research in immersion contexts. The elicitation instruments are then described and findings are presented and discussed concerning the adolescent native speakers' use of question forms, conditionals, and second-person pronouns across two levels of formality in written and oral production. The article concludes with implications for second language instruction.
\end{abstract}

IN AN EXPERIMENTAL STUDY RECENTLY undertaken in French immersion (FI) classrooms (Lyster, 1993, 1994), it was demonstrated that the explicit teaching of sociostylistic variation can have a positive effect on specific aspects of second language (L2) learners' sociolinguistic competence. The study was modeled after two other studies, both of which had been concerned with aspects of FI students' grammatical competence (Harley, 1989; Day \& Shapson, 1991). While there is generally little disagreement among L2 educators concerning what constitutes grammatically correct French, there is less consensus concerning sociolinguis-

The Modern Language Journal, 80, ii (1996) 0026-7902/96/165-182 \$1.50/0

๑1996 The Modern Language Journal tic features. Sociolinguistic competence is characterized by considerable variation in accordance with social context, so certain features are not necessarily right or wrong, but rather more or less appropriate. Given the fluid and relative nature of sociolinguistic appropriateness, it was imperative that analyses of $L 2$ learners' performance in the experimental study take close account of native speakers' sociostylistic variation. Consequently, in order to provide the data required to establish rating scales for the experimental study, the investigator undertook a study to detect the sociolinguistic norms apparent in the use of three language features in the written and oral production of adolescent native speakers in formal and informal contexts.

A set of tasks designed to assess sociostylistic variation was administered to a sample of native 
speakers composed of adolescent francophones attending a high school in the Quebec City area in the province of Quebec. The investigator examined language features in formal letters and informal notes written by this sample of 81 native speakers. Features included direct and indirect questions, the conditional mood, and second-person pronouns. Similarly, the investigator examined the use of questions, conditionals, and second-person pronouns in a variety of speech acts performed by a subsample of 44 adolescent native speakers in a series of simulated formal and informal oral contexts. With a view to providing helpful information to L.2 educators, the purpose of the present article is to characterize the adolescent native speakers' sociostylistic variation with respect to these three features across two levels of formality in written and oral French.

\section{SOCIOLINGUISTIC COMPETENCE AND L2 LEARNERS}

The ability of native speakers to vary language in accordance with social context is generally considered to derive from their communicative competence, a construct proposed by Hymes (1971) which entails, in addition to knowledge of linguistic forms, the ability to use linguistic forms appropriately. Gumperz (1972) writes that a speaker's communicative competence describes "his ability to select, from the totality of grammatically correct expressions available to him, forms which appropriately reflect the social norms governing behaviour in specific encounters" (p. 205).

The construct of communicative competence has been further elaborated on by L2 theorists for the purpose of facilitating the development of L2 testing procedures and curriculum materials. Canale and Swain (1980) and Canale (1983) propose that communicative competence consists minimally of grammatical, discourse, sociolinguistic, and strategic competencies, all of which interact in a nonisolable fashion during language performance. Sociolinguistic competence, in their model, is characterized as the ability to produce and recognize socially appropriate language in context (see also Bachman, 1990).

Research undertaken to assess the L2 proficiency of FI students in Canada has revealed weaknesses in their sociolinguistic competence relative to that of native speakers of the same age. In Harley, Cummins, Swain, and Allen (1990) (see also Harley, Allen, Cummins, \&
Swain, 1987), a set of tests designed to assess sociolinguistic competence indicated that FI students at the Grade 6 level performed significantly differently from native speakers of the same age on sociolinguistic measures of oral and written production. In both written and oral production, for example, FI students achieved significantly lower scores than native speakers in their use of vous and conditional verb forms to express politeness. Based on the same oral production measure adapted for high school students, results presented in Swain and Lapkin (1990) indicate that this nonnative-like sociolinguistic competence of FI students remains as such into their high school years. Comparing samples of early FI students, late FI students, and native speakers of the same age, Swain and Lapkin found that early FI students continued to overuse $t u$ in formal situations compared to native speakers (and also compared to late immersion students), and that both early and late FI students used significantly fewer conditionals in formal situations than did native speakers.

Based on observations of 10 Grade 6 FI classrooms in Ontario, Swain and Carroll (1987) suggest that the almost exclusive use of $t u$ by early immersion students can be partially explained by the absence in FI classrooms of the social function of vous as a marker of formality. Formal situations requiring the teacher to use vous are rare in the classroom-teachers generally say $t u$ to individual students and to fellow teachers. However, early FI students also use $t u$ when addressing more than one person (Harley, 1986), indicating that they have not only failed to acquire the social function of vous, but also its grammatical function as plural marker. Yet the grammatical function of vous is indeed available in the teachers' input because vous is generally, although not always, used to address the whole class. ${ }^{1}$ Swain and Carroll found that while teachers used $t u$ and vous about equally often $(52.7 \%$ and $47.3 \%$ respectively), students used $t u 96 \%$ of the time and vous only $4 \%$ of the time, and that of all contexts requiring a second-person pronoun, only $1.3 \%$ required use of the plural form. Thus, vous as a marker of formality is generally absent from the input available to students in the classroom, whereas vous as a marker of plurality is available in the input but opportunities for students to produce vous to mark plurality are infrequent.

Because classroom interaction is neither adequately rich nor sufficiently varied to allow FI students to learn the sociolinguistic functions 
of second-person pronouns and conditional forms, these L2 learners may not be able to make other choices concerning sociostylistic variation. Indeed, recent research suggests that immersion students learn an academic register of the L2 but not its vernacular. Tarone and Swain (1995) provide anecdotal evidence that immersion students do not acquire colloquial lexical variants that might otherwise facilitate more authentic L2 communication among peers. With respect to phonological variables, Sankoff and Thibault (1995) have demonstrated that anglophone graduates of French immersion programs in Quebec do not necessarily produce features of the Quebec vernacular as common as / $/$ deletion in subject pronouns and affrication of $/ d /$ and $/ t /$ before high front vowels $(/ \mathrm{i} /, / \mathrm{y} /$, as in $l u n d i, d u, t u$, petit, etc.).

Given immersion students' difficulties in varying their L2 in accordance with social context, researchers have suggested that these students could benefit from classroom intervention involving functionally oriented instruction and opportunities for practice in sociostylistic variation (Allen, Swain, Harley, \& Cummins, 1990; Harley et al., 1987; Lyster, 1993; Swain \& Lapkin, 1990). Accordingly, if it is proposed that sociostylistic variation should receive explicit attention in L2 classrooms (see also Tarone \& Swain, 1995, p. 175), then what are the authentic points of reference for such intervention? Whereas there exist numerous dictionaries and reference grammars to support the teaching of lexis and syntax, there are no such reference books to support the teaching of sociostylistic variation. Although it is true that dictionaries and current reference grammars generally differentiate formal and informal styles, it remains difficult to document the more fluid sociolinguistic "rules" that come into play when linguistic features such as second-person pronouns, various question forms, and conditional verb inflections combine differentially to produce, for example, requests, complaints, or offers addressed either to close friends or to unknown adults.

In this regard, the present study aims to examine adolescent francophones' use of questions, conditional forms, and second-person pronouns in a variety of written and oral tasks. These features were considered to aim to preserve "negative face" as outlined by Brown and Levinson (1987), namely, the addressee's desire to remain unimpeded and free from imposition. Negative face may be preserved by creat- ing social distance, as in the use of singular vous, or indirectness, as in the use of questions and the conditional mood-modalities that allow the addressee to feel that he or she has the option of accepting or refusing a request (see also Lakoff, 1977).

An example of uncertainty concerning at least one of these features can be drawn from the Canadian context where one often has the impression that the use of $t u$ is becoming increasingly widespread, particularly among young people; it is not uncommon to hear people speculate that vous may even become an obsolete marker of politeness as levels of formality in social interactions appear to decrease. In the light of such impressions, it becomes important to turn to empirical research to support the teaching of sociostylistic variation.

\section{DATA ELICITATION AND RESULTS}

The native-speaker data in the present study were elicited through a written production test and an oral production test, each of which had two forms, Form A and Form B. The tests were adapted from measures designed for the Development of Bilingual Proficiency (DBP) study outlined in Harley et al. (1990) and described in detail in Allen, Cummins, Mougeon, and Swain (1983) and Harley et al. (1987). The tests in the DBP study had been designed to assess the ability of L2 learners, relative to that of native speakers, to vary their use of certain language features in accordance with the degree of formality determined by social context.

The tests in the present study were administered to a group of native speakers in a secondary school in a relatively middle-class suburb of Quebec City in the province of Quebec. The school had been selected because of its francophone homogeneity and its similarity, in terms of socioeconomic status, to the immersion schools used in the experimental study (Lyster, 1994). Three French language arts classes were made available to the investigator during the 3-day testing period: two Secondaire 2 classes, corresponding to the Grade 8 level and composed of students 13 to 14 years old, and one Secondaire 3 class, corresponding to Grade 9 and composed of students 14 to 15 years old.

The written production test was administered to the total sample of 81 subjects, including 40 females and 41 males. Students were randomly assigned either Form A or Form B. The oral production test was administered individually to a subsample of 44 subjects (21 females and 23 
males), which included the first 13 students whose names appeared on the alphabetized class list for each of the Grade 8 classes and the first 18 students on the Grade 9 class list. Forms $A$ and $B$ of the oral production test were assigned to alternate students in sequence. Students were told before doing the tasks (without being made aware of the sociolinguistic focus) that there were no "right" or "wrong" answers, but that the investigator, for research purposes, was concerned with documenting the ways in which native speakers actually use French in various contexts. Only results of students who indicated French as their mother tongue were included in the data.

What follows is a description of the tasks used to elicit data in written and oral production and the analyses of the native speakers' use of questions, conditional forms, and second-person pronouns. Within-form analyses, comparing the frequency of each feature as used by the same subjects across formal and informal contexts, were undertaken using McNemar's test for related samples (see, for example, Hatch \& Lazaraton, 1991, pp. 417-420). Between-form analyses, comparing the frequency of each feature as used by different subjects performing different tasks at the same level of formality, were undertaken using the chi-square test of independence. Because the degrees of freedom in this study are always equal to 1, Yates's correction for continuity has been applied in the case of the chi-square analyses.

\section{Written Production Test}

The written production (WP) test consists of two tasks - the writing of an informal note and the writing of a formal letter. The informal task on Form A entails a situation in which students have been remiss in tidying their bedroom and the living room even though company is expected that evening. They are asked to write the note that their mother would likely write to them in that situation. On Form B, it is explained to students that they have neglected to complete their homework twice during the same week and that their teacher has asked them to come to class early in order to catch up. Upon arrival in the morning, the teacher is not in the class but has left a note explaining what to do. Students are to write the note that the teacher would have written.

In the formal task on Form A, a situation is described to students in which they have moved with their family into a new apartment where the landlord does not allow dogs. They are asked to write a letter to the landlord persuading him to allow the dog to stay. The context for the formal letter on Form B also involves writing a letter to a landlord. It is explained to students that they are spending the summer with their family in a cottage they have rented. Having noticed a 10-speed bicycle in the locked garage, the students write to the landlord requesting permission to use the bicycle.

Table 1 displays the number and percentage of native speakers using questions, conditionals, and vous in the combined forms ( $A$ and $B$ ) of the notes and in the combined forms (A and B) of the letters. Also indicated in Table 1 are the $p$ values generated by McNemar's test, which confirm that native speakers used a significantly higher proportion of each feature in the letters than in the notes.

TABLE 1

Number and Percentage of Native Speakers $(N=$ 81) Using Questions, Conditionals, and Vous in Combined Forms (A and B) of Notes and Letters (Within-form Comparisons)

\begin{tabular}{lccc}
\hline \hline & Notes & Letters & $p$ \\
\hline Questions & $5(6.2 \%)$ & $39(48.1 \%)$ & .0000 \\
Conditionals & $11(13.6 \%)$ & $54(66.7 \%)$ & .0000 \\
Vous & 0 & $78(96.3 \%)$ & .0000 \\
\hline
\end{tabular}

Table 2 displays the number and percentage of native speakers using questions, conditionals, and vous in the different tasks (Form A vs. Form B), and the percentage is illustrated by the graph in Figure 1. Table 2 also displays between-form comparisons of the writing tasks. The $p$ values generated by the chi-square analysis reveal two significant differences: More native speakers used the conditional in the note from the mother than in the note from the teacher, and more used questions in the letter about the bicycle than about the dog (the latter was frequently written as more of a complaint or justification than as a request for permission). The chi-square test revealed no significant differences between male and female students in their use of the three features in written production. ${ }^{2}$

Questions. The adolescent native speakers used indirect questions and direct yes/no questions to request permission in ways that provided the landlords with the option of granting or refusing the permission to use the bicycle or to keep the dog. Table 3 presents the distribution of question forms occurring in formal 
TABLE 2

Number and Percentage of Native Speakers Using Questions, Conditionals, and Vous in Notes and Letters (Between-form Comparisons)

\begin{tabular}{llccccc}
\hline \hline & $\begin{array}{c}\text { Form A } \\
\text { Note from } \\
\text { mother } \\
(n=40)\end{array}$ & $\begin{array}{c}\text { Form B } \\
\text { Note from } \\
\text { teacher } \\
(n=41)\end{array}$ & $\begin{array}{c}\text { Form A } \\
\text { Letter about } \\
\text { dog } \\
(n=40)\end{array}$ & $\begin{array}{c}\text { Form B } \\
\text { Letter about } \\
\text { bicycle } \\
(n=41)\end{array}$ & $p$ \\
\hline Questions & $4(10 \%)$ & $1(2.4 \%)$ & $n s$ & $13(32.5 \%)$ & $26(63.4 \%)$ & .01 \\
Conditionals & $9(22.5 \%)$ & $2(4.9 \%)$ & .05 & $23(57.5 \%)$ & $31(75.6 \%)$ & $n s$ \\
Vous & 0 & 0 & - & $40(100 \%)$ & $38(92.7 \%)$ & $n s$ \\
\hline
\end{tabular}

FIGURE 1

Percentage of Native Speakers Using Questions, Conditionals, and Vous in Notes and Letters

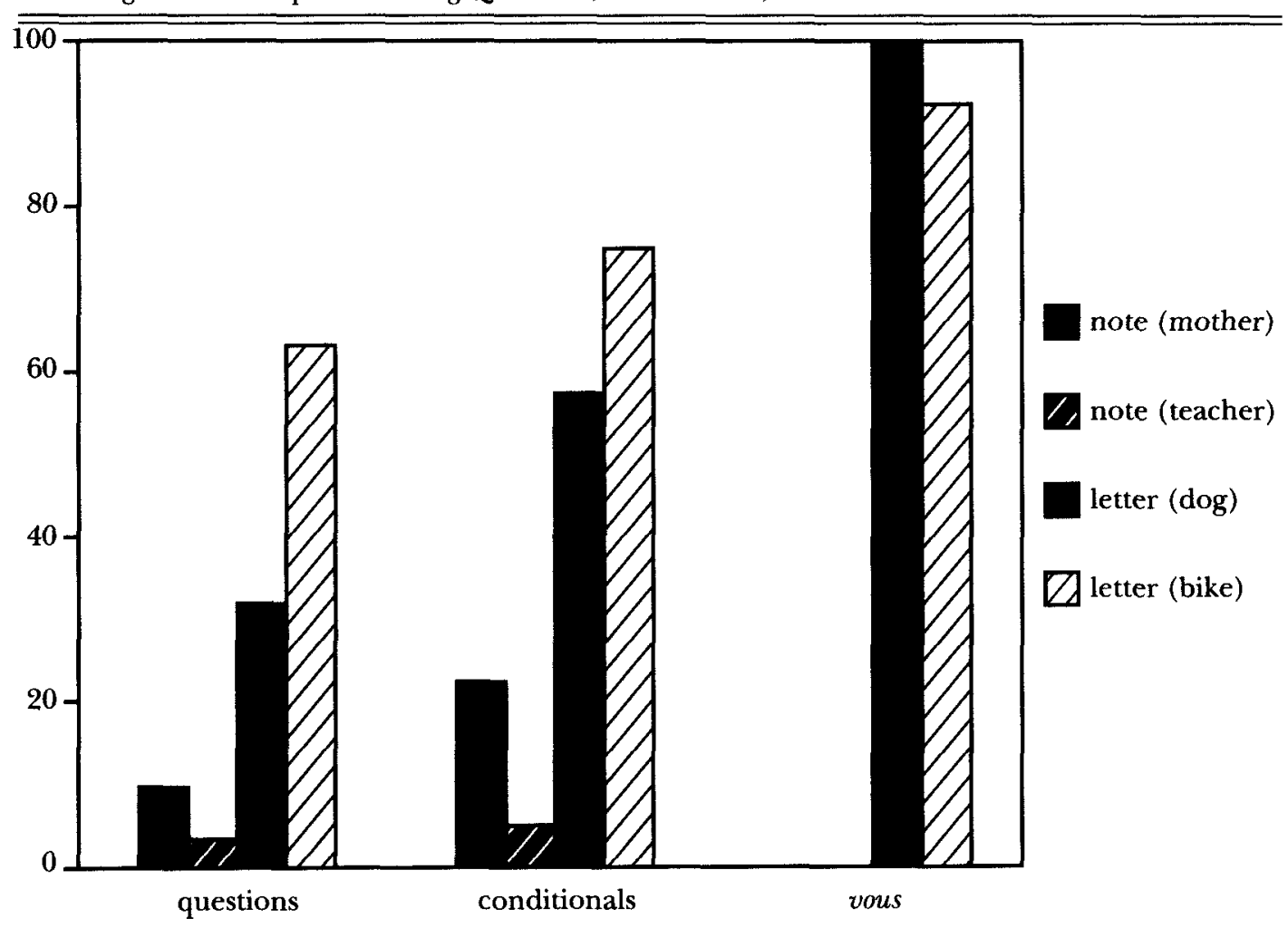

letters. Of the 38 questions, 27 (71\%) were indirect and $11(29 \%)$ were direct. Among the 27 indirect questions, three constructions were used: (a) demander si $(n=17)$, as in "Je vous écris pour vous demander si je peux utiliser votre bicyclette," 3 (b) demander de $(n=5)$, as in "Je vous écris pour vous demander de maccorder la permission ... ," and (c) demander+ Noun Phrase $(n=5)$, as in "Je vous écris pour vous demander la permission. . . ." Of the 11 direct questions, 5 used est-ce que (e.g., "Est-ce que je pourrais la prendre pendant mon séjour?"), 5 used inversion (e.g., "Voudriez-vous me donner la permission..."), and 1 was unimverted. All three information questions began with pourquoi and did not function as politeness markers in that they aimed to directly elicit an explanation: "Pourquoi ne voulez-rous pas que je garde mon petit chien?"; "Pourquoi vous ne voulez pas que je le garde?"; "Pourquoi est-elle là?"All five questions found in notes were direct: Four used inversion, as in "Pourraistu faire le ménage. ...,"whereas only one used est-ce que. Question formation relative to degree of formality will be discussed below with regard to the adolescent native speakers' performance in oral production.

Conditionals. In the formal letters, 54 subjects used at least one conditional, whereas 11 subjects each used one conditional in the informal notes. Several subjects used more than one con- 
TABLE 3

Distribution of Question Forms in Letters

\begin{tabular}{cr}
\hline \hline Indirect questions $(n=27)$ & 17 \\
Demander si & 5 \\
Demander de & 5 \\
Demander + Noun Phrase & \\
Direct questions $(n=11)$ & 5 \\
Yes/no questions $(n=8)$ & 3 \\
Est-ce que & 0 \\
Inverted & \\
Uninverted & 0 \\
Information questions $(n=3)$ & 2 \\
Est-ce que & 1 \\
Inverted & \\
Uninverted &
\end{tabular}

ditional in the letter; as a result, the total number of conditionals appearing in letters is 80 . As displayed in Table 4, the conditional mood was used to fulfill at least two functions: a sociolinguistic function and a grammatical function (see Harley \& Swain, 1984, p. 303).

TABLE 4

Distribution of Conditionals in Letters $(N=80)$

\begin{tabular}{lr}
\hline \hline \multicolumn{2}{l}{ Sociolinguistic function: attenuating conditionals } \\
$(n=53)$ \\
Attenuate statement \\
$\quad$ Aimerais/ voudrais + infinitive \\
$\quad$ Aimerais que + subjunctive & 24 \\
Attenuate indirect question & 7 \\
$\quad$ Conditional in main clause & 9 \\
$\quad$ Conditional in subordinate clause & 6 \\
Attenuate direct question & 7 \\
Grammatical function: hypothetical conditionals \\
$(n=27)$ \\
$\quad$ Statements with si \\
$\quad$ (the condition stated) \\
$\quad$ Statements without $s i$ \\
$\quad$ (the condition implied)
\end{tabular}

a Six statements each contained two conditionals: one in the protasis and one in the apodosis.

Of the 80 conditionals, 53 served the sociolinguistic function of attenuating requests for permission. Of these, 31 conditionals served to attenuate statements expressing the writer's wish or purpose in writing by making his or her commitment appear less emphatic (see Battye \& Hintze, 1992, p. 292). These conditionals were followed either by infinitive verb forms (e.g., "j'aimerais pouvoir l'utiliser") or subjunctive forms (e.g., "j'aimerais bien que vous me la passiez"). Of the remaining 22 attenuating conditionals, 15 were used to attenuate indirect questions. These were used either in the main clause to intro- duce the indirect question (e.g., "Je voudrais vous demander. . .") or in the subordinate clause as part of the indirect question (e.g., "Je vous écris pour vous demander si vous voudriez bien me la prêter."). The other 7 conditionals served to attenuate direct questions (e.g., "Est-ce que vous pourriez me la prêter?").

The grammatical function of expressing a hypothetical outcome was apparent in the use of 27 conditionals. Of these, 12 conditionals were found in six statements using si clauses (e.g., " $l l$ me ferait grandement plaisir si vous accepteriez qu il demeure avec moi."). All six subjects used the conditional mood in the apodosis to express the hypothetical outcome as well as in the protasis to express the condition itself, contrary to standard usage, which prescribes the use of the imperfect tense in the protasis. The remaining 15 conditionals referred to hypothetical outcomes without the use of $s i$; in these cases, the condition-if you accept or if you do not accept-was left implicit. Seven of these statements referred to a negative outcome thus implying nonacceptance,' as in "ce serait terrible pour moi de m'en séparer" ("it would be terrible for me to be separated from it"), whereas 8 referred to a positive outcome and implied acceptance, as in "Elle me serait très utile" ("It would be very useful to me"). By referring only hypothetically to the desired outcome of a request in this way, the writer appears not to take the permission for granted and thereby implies that the addressee has the option of accepting or refusing. The addressee is thus able to feel less pressured to do what is asked than if the indicative future tense had been used. Thus, both the grammatical function and the sociolinguistic function of the conditional mood served a common politeness function by reducing directness and, concomitantly, imposition.

Second-person pronouns. Tu was consistently used in notes and vous was used almost exclusively in formal letters. Among the 81 native speakers, 78 consistently used vous in the formal letters, making it clear that vous is "de rigueur" in such formal correspondence. Only one native speaker avoided the use of second-person pronominal reference in what was a relatively short letter. Another native speaker was the only one to combine $t u$ and vous forms in a particularly deviant letter. One other native speaker wrote a relatively lengthy and polite formal letter using vous consistently throughout, but then concluded with the expression "silteplait," spelled as one word. ${ }^{4}$ 


\section{Oral Production Test}

The oral production (OP) test was an adaptation of the version used in the DBP study (Harley et al., 1987; Harley et al., 1990). There were two different forms, each consisting of five formal situations and five informal situations. Students were tested individually in a small room near the classroom. They were shown slides of the people they were to address while the investigator described the hypothetical situation and tape-recorded their responses. Before beginning the test, female subjects were shown a slide of a girl named Lise and were told to imagine that they were best friends at school. The same was asked of male subjects while showing them a slide of a boy named Jean. These two characters then appeared throughout the test in the informal situations. In the case of unknown adults appearing in formal situations throughout the test, females were shown a slide of a woman, and males were shown a slide of a man. An example was done before the test began in order to verify that students understood the task.

Form $A$. Situation 1 takes place upon the students' return to school after a 3-day absence. Needing some help to catch up in math, they first must ask their friend, Lise or Jean, and then their math teacher, Monsieur Desroches, for help. Situation 2 occurs in the library where students have been sent to complete a math test they missed during their absence. There are two people talking at a nearby table in the library, and this prevents them from completing the exam. Students are asked to imagine asking the people to speak more quietly. They are to respond to this situation first as if the noisy people were two classmates, one of whom is either Lise or Jean, and then as if they were two unknown adults. In Situation 3, students are watching a show in the auditorium and notice someone whose view is blocked by a column. Students offer the person a nearby empty seat with a better view. In the first context, the addressee is an unknown adult, and in the second, students offer the seat to their friend. In Situation 4, students are visiting Montreal and are to ask someone how to get to the Olympic Stadium-first they ask an unknown adult and then a friend. In Situation 5, students are given a map of the old quarter of Quebec City; they are asked to respond first to a friend and then to an unknown adult, both of whom request directions.

Form B. In Situation 1, students are studying in the library and need to borrow a ruler. They first ask their friend and then the librarian who is working behind the counter. In Situation 2, students are waiting in line for a meal in the cafeteria and are being pushed by the person behind them. They are to react to the person, first as if it were their friend, and then as if it were an unknown adult. In Situation 3, students offer to help someone carrying an armful of books at school. The first addressee is an unknown teacher, and the second is a friend. In Situation 4, students are visiting the city of Trois-Rivières and wish to go to the cinema. They ask for directions, first from an unknown adult and then from a peer. For Situation 5, students are given a map of the old quarter of Quebec City and are to react first to a friend and then to an unknown adult in response to a request for directions.

Questions. Five different question forms were used by native speakers in the oral production tasks: (a) simple inversion (without nominal subjects), (b) est-ce que, (c) uninverted forms (rising intonation with declarative word order), (d) use of the interrogative suffix -tu (e.g., "Je peux-tu t'aider?"), 5 and (e) indirect questions, as in " $J e$ voulais juste vous demander par quelle direction ..." ("I just wanted to ask you what direction ...").

Table 5 presents the number of subjects using the different question forms when addressing a peer, whereas Table 6 presents question forms used when addressing an adult. The strategies preferred by this sample of adolescents to address peers included use of the interrogative suffix $-t u(25 \%)$, inversion $(24.4 \%)$, est-ce que $(23.9 \%)$, or no questions at all $(23.3 \%)$, whereas in more formal situations their preferred strategies included the use of inversion (42\%) and estce que (37.5\%). Comparisons of these four strategies across formal and informal contexts are presented in Table 7. $P$ values computed by McNemar's test indicate that subjects used inversion significantly more frequently to address adults than to address peers when requesting directions. A significantly higher proportion of subjects used est-ce que questions to address adults than to address peers when complaining and when offering assistance. The use of $-t u$ as interrogative suffix was significantly higher in all informal situations, being reserved exclusively to address peers, with the exception of one subject who asked to borrow the librarian's ruler by saying, "Je pourrais-tu prendre la règle, sill vous plaît?" With regard to the absence of questions, only the speech act of offering yielded significantly fewer questions in informal situations. 
TABLE 5

Number of Question Types Used by Subjects to Address Peers in Oral Production Tasks (in decreasing order)

\begin{tabular}{lcccccccc}
\hline \hline & $\begin{array}{c}\text { Request } \\
\text { help } \\
(n=22)\end{array}$ & $\begin{array}{c}\text { Request } \\
\text { ruler } \\
(n=22)\end{array}$ & $\begin{array}{c}\text { Complain } \\
\text { about } \\
\text { noise } \\
(n=22)\end{array}$ & $\begin{array}{c}\text { Complain } \\
\text { about } \\
\text { pushing } \\
(n=22)\end{array}$ & $\begin{array}{c}\text { Offer } \\
\text { seat } \\
(n=22)\end{array}$ & $\begin{array}{c}\text { Offer } \\
\text { help } \\
(n=22)\end{array}$ & $\begin{array}{c}\text { Request } \\
\text { directions } \\
(n=44)\end{array}$ & Total \\
\hline -tu suffix & 3 & 12 & 6 & 4 & 1 & 5 & 13 & $44(25.0 \%)$ \\
Inversion & 4 & 4 & 8 & 5 & 4 & 7 & 11 & $43(24.4 \%)$ \\
Est-ce que & 13 & 4 & 2 & 1 & 0 & 6 & 16 & $42(23.9 \%)$ \\
No question & 2 & 0 & 5 & 12 & 18 & 4 & 0 & $41(23.3 \%)$ \\
Uninverted & 0 & 2 & 0 & 0 & 0 & 0 & 3 & $5(2.8 \%)$ \\
Indirect & 0 & 0 & 1 & 0 & 0 & 0 & 0 & $1(0.6 \%)$ \\
\hline
\end{tabular}

TABLE 6

Number of Question Types Used by Subjects to Address Adults in Oral Production Tasks (in decreasing order)

\begin{tabular}{lcccccccc}
\hline \hline & $\begin{array}{c}\text { Request } \\
\text { help } \\
(n=22)\end{array}$ & $\begin{array}{c}\text { Request } \\
\text { ruler } \\
(n=22)\end{array}$ & $\begin{array}{c}\text { Complain } \\
\text { about } \\
\text { noise } \\
(n=22)\end{array}$ & $\begin{array}{c}\text { Complain } \\
\text { about } \\
\text { pushing } \\
(n=22)\end{array}$ & $\begin{array}{c}\text { Offer } \\
\text { seat } \\
(n=22)\end{array}$ & $\begin{array}{c}\text { Offer } \\
\text { help } \\
(n=22)\end{array}$ & $\begin{array}{c}\text { Request } \\
\text { directions } \\
(n=44)\end{array}$ & Total \\
\hline Inversion & 5 & 8 & 12 & 10 & 5 & 10 & 24 & $74(42.0 \%)$ \\
Est-ce que & 10 & 13 & 7 & 4 & 3 & 12 & 17 & $66(37.5 \%)$ \\
No questions & 6 & 0 & 2 & 7 & 14 & 0 & 1 & $30(17.0 \%)$ \\
Uninverted & 1 & 0 & 1 & 1 & 0 & 0 & 1 & $4(2.7 \%)$ \\
tu suffix & 0 & 1 & 0 & 0 & 0 & 0 & 0 & $1(0.6 \%)$ \\
Indirect & 0 & 0 & 0 & 0 & 0 & 0 & 1 & $1(0.6 \%)$ \\
\hline
\end{tabular}

TABLE 7

Number of Native Speakers $(N=44)$ Using Each Question Type per Speech Act to Address Peers and Adults in Combined Forms (A and B) of Oral Production Tasks (Within-form Comparisons)

\begin{tabular}{|c|c|c|c|c|c|c|c|c|c|c|c|c|}
\hline & \multicolumn{2}{|c|}{ Inversion } & \multirow[b]{2}{*}{$p$} & \multicolumn{2}{|c|}{ Est-ce que } & \multicolumn{3}{|c|}{$-t u$ suffix } & \multicolumn{4}{|c|}{ No question } \\
\hline & To peer & To adult & & To peer & To adult & $p$ & To peer & To adult & $p$ & To peer & To adult & $p$ \\
\hline $\begin{array}{l}\text { Request } \\
\text { help/ruler }\end{array}$ & 8 & 13 & $n s$ & 17 & 23 & $n s$ & 15 & 1 & .0001 & 2 & 6 & $n s$ \\
\hline Complain & 13 & 22 & $n s$ & 3 & 11 & .02 & 10 & 0 & .002 & 17 & 9 & $n s$ \\
\hline Offer & 11 & 15 & $n s$ & 6 & 15 & .02 & 6 & 0 & .03 & 22 & 14 & .04 \\
\hline $\begin{array}{l}\text { Request } \\
\text { directions }\end{array}$ & 11 & 24 & .001 & 16 & 17 & ns & 13 & 0 & .0002 & 0 & 1 & ns \\
\hline
\end{tabular}

Table 8 presents the distribution of all questions occurring in the oral production corpus (a small number of native speakers used more than one question per speech act). Of the 286 questions, most were yes/no questions ( $94.4 \%)$. Inversion and est-ce que questions were quite evenly distributed and together accounted for $80 \%$ of all questions, whereas there were very few uniniverted questions (3.5\%). Of the 101 yes/no questions using est-ce que, over half began with one of the three following phrases: "Est-ce que vous pourriez...." ( $n=22)$, "Est-ce que je peux ..." $(n=22)$, or "Est-ce que je pourrais . .." $(n=10)$. Of the 119 inverted yes/no questions, over half began with one of the following: "Pourriez-vous ..." $(n=37)$, "Pourrais-tu ..." $(n=13)$, or "Peux-tu $\ldots "(n=12)$. Of the 45 questions using the $-t u$ particle, over half were represented by the following: "Tu peux-tu . . ." $(n=10)$, "Tu me prêtes-tu ..." $(n=8)$, or "Tu pourrais-tu ..." $(n=7)$. Only $5.6 \%$ of all questions in the corpus were information questions using question words (que, où, quand, or comment). All eight information questions using est-ce que involved the use of qu'est-ce que (e.g., "Qu'est-ce que vous avez fait . . ."); the three inverted information questions contained où (e.g., "Oǹ se situe le Stade Olympique?"); the five uninverted information questions used 
either où (e.g., "C'est où le Cinéma Lumières?"), quand ("La prochaine récupération en mathématiques, c'est quand?") or comment ("Comment je peux y aller?"). The interrogative suffix $-t u$ did not occur in information questions.

TABLE 8

Distribution of Question Forms in Oral Production Corpus

\begin{tabular}{|c|c|c|}
\hline \multicolumn{3}{|c|}{ All questions $(N=286)$} \\
\hline Est-ce que & 109 & $(38.1 \%)$ \\
\hline Inverted & 122 & $(42.7 \%)$ \\
\hline Uninverted & 10 & $(3.5 \%)$ \\
\hline$-t u$ suffix & 45 & $(15.7 \%)$ \\
\hline \multicolumn{3}{|c|}{ Yes/no questions $(n=270)$} \\
\hline Est-ce que & 101 & $(37.4 \%)$ \\
\hline Inverted & 119 & $(44.0 \%)$ \\
\hline Uninverted & 5 & $(1.9 \%)$ \\
\hline$-t u$ suffix & 45 & $(16.7 \%)$ \\
\hline \multicolumn{3}{|c|}{ Information questions $(n=16)$} \\
\hline Est-ce que & 8 & $(50.0 \%)$ \\
\hline Inverted & 3 & $(18.8 \%)$ \\
\hline Uninverted & 5 & $(31.2 \%)$ \\
\hline$-t u$ suffix & 0 & \\
\hline
\end{tabular}

Conditionals. Table 9 displays the number and percentage of native speakers using at least one conditional in each of the oral production tasks, as well as the significance levels computed by McNemar's test comparing frequencies across formal and informal situations. A significantly higher proportion of subjects used the conditional to address an adult than to address a friend when asking to borrow a ruler, complaining about being pushed, offering to carry books, and requesting directions. The chisquare test revealed only one significant difference in the between-form comparisons: A higher number of subjects used the conditional to complain to a friend about loud talking in the library than to ask a friend to stop pushing $(p=.03)$.
As we can see in Table 9 and the graph in Figure 2, more conditionals were used overall in formal situations than in informal situations. However, it is also clear that the use of conditionals varies according to the speech act itself, regardless of the level of formality. For example, $40.9 \%$ of the native speakers used the conditional to ask their friend for help in math, and $54.5 \%$ used it to ask their friend to be quiet in the library. However, only $18.2 \%$ of the native speakers used the conditional to offer a seat to the unknown adult, and $36.4 \%$ used it to offer help to the unknown teacher by carrying books.

With the exception of giving directions, which elicited, as expected, no conditionals, ${ }^{6}$ offers were clearly the one speech act that generated significantly fewer conditionals relative to all other speech acts. According to McNemar's test, offers addressed to adults resulted in a significantly smaller proportion of subjects using the conditional in comparison to the request for the ruler or help in math $(p=.01)$, the complaint $(p=.0009)$, and the request for directions $(p=.0009)$. Similarly, in informal situations, significantly fewer subjects used the conditional to offer help or a seat to a friend than to request the ruler or help in math $(p=.01)$, complain ( $p$ $=.0005)$, or request directions $(p .=.01)$.

Second-person pronouns. While the native speakers' use of $t u$ and vous in written production was unambiguous ( $t u$ in notes and vous in letters), the use of $t u$ and vous in the oral situations involved slightly more variability. It was initially hypothesized that adolescent native speakers would invariably use $t u$ to address other adolescents in informal situations, but that there would be considerable variance among adolescents in their use of secondperson pronouns to address adults in more formal situations because the degree of formality in these situations would not necessarily be perceived in identical ways by all individuals. How-

TABLE 9

Number and Percentage of Native Speakers Using at Least One Conditional in Oral Production Tasks (Within-form Comparisons)

\begin{tabular}{llrrrr}
\hline \hline Form & Task & $n$ & To peer & To adult & $p$ \\
\hline A & Request help in math & 22 & $9(40.9 \%)$ & $13(59.1 \%)$ & $n s$ \\
B & Request ruler & 22 & $3(13.6 \%)$ & $12(54.5 \%)$ & .01 \\
A & Complain about noise & 22 & $12(54.5 \%)$ & $17(77.3 \%)$ & $n s$ \\
B & Complain about pushing & 22 & $4(18.2 \%)$ & $13(59.1 \%)$ & .01 \\
A & Offer seat & 22 & $2(9.1 \%)$ & $4(18.2 \%)$ & $n s$ \\
B & Offer to help & 22 & 0 & $8(36.4 \%)$ & .01 \\
A/B & Request directions & 44 & $12(27.3 \%)$ & $29(65.9 \%)$ & .0001 \\
A/B & Give directions & 44 & 0 & 0 & - \\
\hline
\end{tabular}


FIGURE 2

Percentage of Native Speakers Using at Least One Conditional in Oral Production Tasks

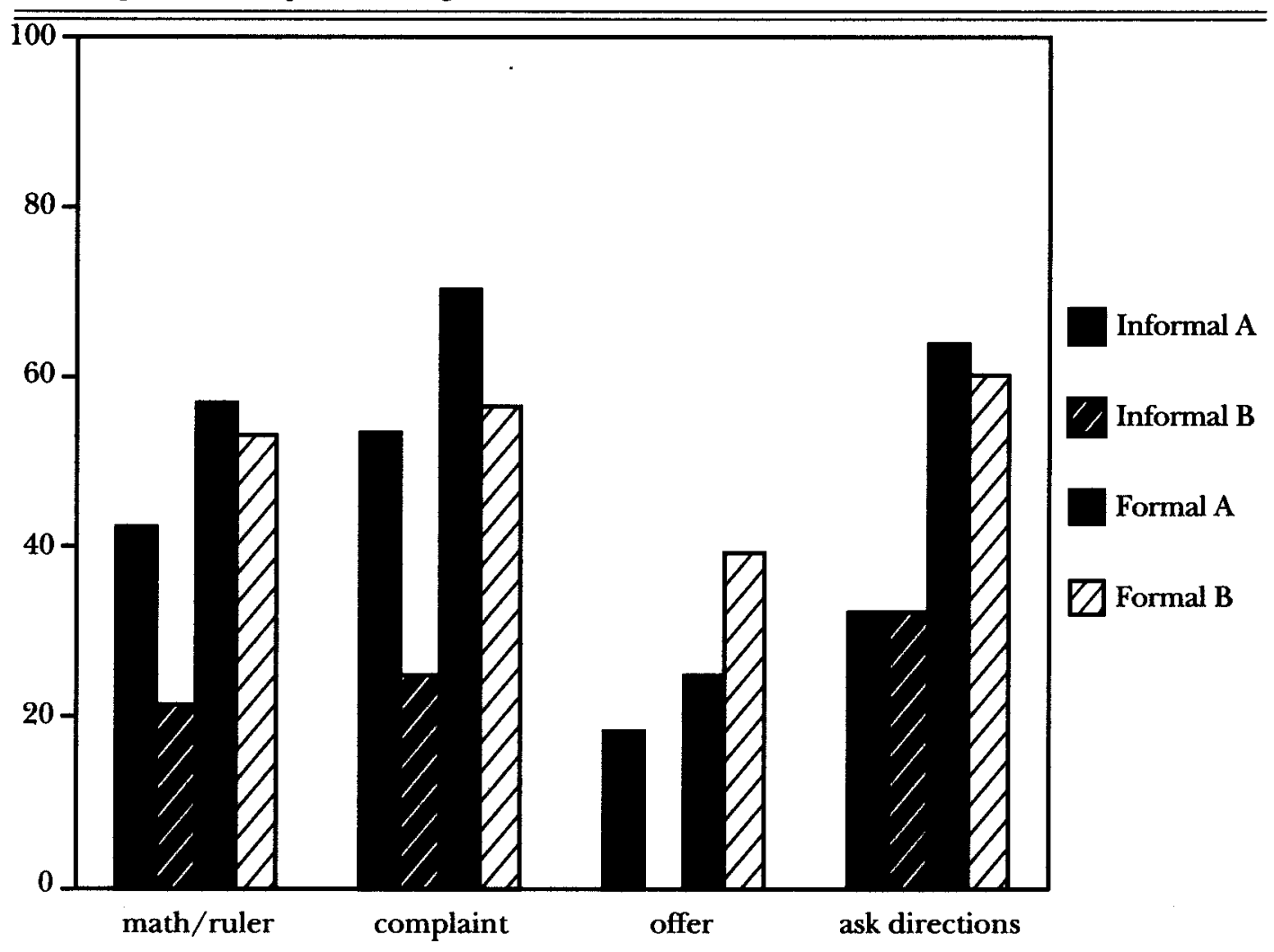

ever, contrary to this initial hypothesis, a surprisingly high level of agreement was found among native speakers in their use of secondperson pronominal reference in both informal and formal situations.

The number of native speakers using $t u$ or vous in the oral production tasks is displayed in Table 10, which also presents the $p$ levels com- puted by McNemar's test comparing the use of second-person pronouns across formal and informal situations. All contrasts are significant. $T u$ is used consistently to address peers, with two exceptions: One native speaker began to give directions to a friend using vous then switched to $t u$, apparently realizing his error; another native speaker used vous to mark plu-

TABLE 10

Number of Native Speakers Using Tu or Vous (and Percentage Using Vous) in Oral Production Tasks (Within-form Comparisons)

\begin{tabular}{|c|c|c|c|c|c|c|c|c|}
\hline \multirow[b]{2}{*}{ Form } & \multirow[b]{2}{*}{ Task } & \multirow[b]{2}{*}{$n$} & \multicolumn{3}{|c|}{ To peer } & \multicolumn{2}{|c|}{ To adult } & \multirow[b]{2}{*}{$p$} \\
\hline & & & Tu & & Vous & $T u$ & Vous & \\
\hline A & Request help in math & 22 & 17 & 1 & $(4.5 \%)$ & 2 & $15(68.2 \%)$ & .001 \\
\hline B & Request ruler & 22 & 22 & 0 & & 2 & $19(86.4 \%)$ & .0000 \\
\hline$A$ & Complain about noise & 22 & 22 & 0 & & 0 & $21(95.4 \%)$ & .0000 \\
\hline B & Complain about pushing & 22 & 22 & 0 & & $\mathbf{5}$ & $17(77.3 \%)$ & .0000 \\
\hline $\mathbf{A}$ & Offer seat & 22 & 21 & 0 & & 0 & $21(95.4 \%)$ & .0000 \\
\hline B & Offer to help & 22 & 22 & 0 & & 1 & $21(95.4 \%)$ & .0000 \\
\hline A/B & Request directions & 44 & 40 & 0 & & 0 & $39(88.6 \%)$ & .0000 \\
\hline A/B & Give directions & 44 & 44 & 1 & $(2.3 \%)$ & 1 & $43(97.7 \%)$ & .0000 \\
\hline
\end{tabular}

Note. For each situation, the number of subjects using $t u$ added to the number using vous is not always equal to 22 or 44 because second-person reference was avoided in questions such as "C'est où le Stade Olympique?" ("Where's the Olympic Stadium?") and "Qu'est-ce qu'on a fait hier dans le cours?" ("What did we do yesterday in class?"). 
rality when asking her friend what was done in the math class ("Lise, en mathématiques, qu'est-ce que vous avez fait aujourd'hui?").

Vous was used consistently to address adults, with the following exceptions: Two native speakers used $t u$ to request help in math from the teacher (although one of these subjects switched to vous in the middle of her utterance); two native speakers used $t u$ to request to borrow the librarian's ruler; five native speakers used $t u$ to address the unknown adult pushing them in line; one native speaker used $t u$ to offer to carry an unknown teacher's books; one native speaker hesitatingly combined $t u$ and vous forms to give directions to an unknown adult. The chi-square test revealed no significant difference between male and female subjects in their use of $t u$ and vous in oral production.

\section{SUMMARY AND DISCUSSION}

\section{Questions}

Based on the different question forms used by native speakers in written and oral production, a continuum reflecting degrees of formality may be proposed. Most formal are indirect questions, which prevailed in formal letters yet were virtually absent in oral production. Least formal are questions formed with the interrogative suffix $-t u$, which occurred only in oral production and almost exclusively in informal contexts when addressing peers. Between these two extremes are yes/no questions with simple inversion and est-ce que. These two forms were used by adolescents equally often in overall oral production, but were used more frequently to address adults than to address peers because the interrogative suffix $-t u$ provided an alternative form in the informal contexts.

The data elicited in the present study revealed minimal use of uninverted questions with rising intonation and considerable use of inversion in spoken French, contrary to other studies which indicate that inverted questions occur infrequently in spoken French and that uninverted forms with rising intonation and estce que forms clearly predominate, at least in informal speech (e.g., Coveney, 1990; Gadet, 1989). These studies report findings pertaining to Continental French, which reserves inversion for formal registers (Harris, 1978) and particularly for written French (Grevisse, 1986, § 386; see also McCool, 1994, for pedagogical implications).

The present study's finding that inverted yes/ no questions have not fallen into disuse in spoken
French in Quebec is supported by other studies as well. For example, similar findings have been reported from Île-aux-Coudres: Of the 185 yes/no questions in Seutin's (1975) corpus, 71 (38.4\%) are inverted, 40 (21.6\%) contain est-ce que, and 74 $(40.0 \%)$ contain the interrogative suffix (no information is provided concerning uninverted questions with rising intonation). Barbarie's (1982) sociolinguistic analysis of question forms used by 104 native speakers within a 35 mile radius of Sherbrooke, Quebec, include a total of 436 yes/ no questions elicited during open-ended interviews. He found that yes/no questions using either declarative word order with rising intonation, simple inversion, or the $-t u$ suffix were all equally likely to be used by the same subjects, but that it was questions with est-ce que that set themselves apart as the more formal variant. In Di Sciullo and St-Pierre's (1982) analysis of interrogative and imperative forms in requests made by young Montrealers during unstructured interactions recorded at youth centres in an inner-city neighbourhood in Montreal (for a description of this otherwise large corpus and the methodology, see Doran, Drapeau, \& Lefebvre, 1982), 24 yes/no questions appear. Of these, 11 use simple inversion, 7 use the interrogative suffix $-t u, 3$ use uninverted forms with rising intonation, and 3 use est-ce que. Finally, in the absence of further quantitative studies of question forms in Quebec French, the present author examined question formation in Les Belles-Soeurs (Tremblay, 1968/1972). This is a well-known play by author Michel Tremblay, renowned for his rendering of popular Québécois vernacular. There are 79 yes/no questions in this play (excluding interrogative tags such as Hein? and Non?); of these, 34 (43\%) use uninverted forms with rising intonation, 31 (39.2\%) use simple inversion, $14(17.7 \%)$ use the interrogative suffix $-t u$, and none use est-ce que.

Although these results provide evidence that simple inversion in yes/no questions has been maintained in Quebec and has not become a marked form in informal speech (but see Lightbown, 1980, and Lightbown \& d'Anglejan, 1985), 7 there are doubtless formal and pragmatic constraints related to the elicitation tasks used in the present study that may have contributed to the considerable number of inverted forms in yes/no questions. The oral elicitation tasks in this study made use of a restricted set of language functions: making requests, complaints, and offers. Consequently, there is evidence of at least two constraints related to question formation that might not have arisen in less structured conversations. 
First, the tasks placed restrictions on grammatical person: Of the 270 yes/no questions in the corpus, almost $86 \%$ used second-person pronouns. As third-person reference increases, it seems reasonable to expect that the use of inverted question forms would decrease so as to avoid the inclusion of a euphonic $t$ (Mange-t-il?) and complex inversion ("false" inversion) with nominal subjects (i.e., Pierre vient-il?). Indeed, Barbarie (1982) found no such forms in his corpus and concluded that the use of simple inversion is favoured by the subject pronoun $t u$. Similarly, in Seutin's (1975) corpus, of the 71 inverted yes/no questions, all but 4 involved second-person pronominal reference.

Second, as indicated in Table 11, which displays the different verb tokens found in the 270 yes/no questions, the nature of the tasks restricted verb choice: $86.3 \%$ of these questions contained either the verb pouvoir, vouloir, or savoir. Thus, it may be the case that verbs with the potential to be used modally in French appear more frequently in inverted yes/no questions than verbs that do not function modally. ${ }^{8}$ However, while these verbs may have favoured inverted forms over uninverted forms in the present study, they did not necessarily favour inversion over est-ce que and occurred (with the exception of vouloir) equally often in both question types. The effect of verb choice on question formation is clearly an area worthy of further research.

\section{Conditionals}

The use of conditionals in written production was a relatively good indicator of formality (66.7\% of the letters and $13.6 \%$ of the notes con- tained a conditional), whereas this was less so for conditionals in oral production. In oral production, more conditionals were used overall in formal contexts (subjects used the conditional in $43.6 \%$ of the formal situations and in $19.1 \%$ of the informal situations). However, the use of conditionals varied according to the speech act as well as according to degree of formality. That is, the speech act of offering a seat or offering to carry books, whether addressed to a friend or a stranger, elicited significantly fewer conditionals in comparison to complaints and requests for assistance. Offers are less imposing on the addressee; they are polite due to the nature of the illocutionary act and also due to the use of the direct question, which functions as a request for permission to help (e.g., "Est-ce que je peux vous aider?"). Further mitigation through the use of a polite conditional is unnecessary. In some informal situations, however, conditionals were used to address peers in order to mitigate requests for help or directions as well as to soften the complaint about noise in the library. Thus, the native-speaker data clearly indicate that the conditional may be used as a politeness marker in formal or informal situations.

\section{Second-Person Pronouns}

In written production, the use of vous was "de rigueur" in formal correspondence, even for young adolescents. In oral production, vous was generally used to address unknown adults in situations where directions were being given or requested and where help (or a seat) was being offered. In the case of interactions with a teacher or school librarian known to the adoles-

TABLE 11

Number of Verb Tokens in Yes/no Questions $(N=270)$ in Oral Corpus

\begin{tabular}{lcccrr}
\hline \hline & $\begin{array}{c}\text { Est-ce que } \\
(n=101)\end{array}$ & $\begin{array}{c}\text { Inverted } \\
(n=119)\end{array}$ & $\begin{array}{c}\text { Uninverted } \\
(n=5)\end{array}$ & $\begin{array}{c}\text { tu suffix } \\
(n=45)\end{array}$ & Total \\
\hline Pouvoir & 74 & 78 & 2 & 19 & 173 \\
Vouloir & 6 & 26 & 0 & 3 & 35 \\
Savoir & 11 & 9 & 1 & 4 & 25 \\
Avoir & 1 & 3 & 0 & 5 & 9 \\
Prêter & 0 & 0 & 0 & 9 & 9 \\
Être & 4 & 1 & 0 & 0 & 5 \\
Passer & 0 & 1 & 2 & 1 & 4 \\
Déranger & 1 & 0 & 0 & 1 & 2 \\
Aimer & 0 & 1 & 0 & 0 & 1 \\
Aller & 0 & 0 & 0 & 1 & 1 \\
Faire & 1 & 0 & 0 & 0 & 1 \\
Tenter & 0 & 0 & 0 & 1 & 1 \\
Voir & 0 & 0 & & 1 & 1 \\
\hline
\end{tabular}


cent native speaker or in a face-threatening situation with an unknown adult, the use of vous predominated in utterances produced by native speakers in this study's sample, although the less frequent use of $t u$ was also observed.

These findings generally support the conclusions of other recent studies that indicate that vous is not falling into disuse in Quebec. For example, Thibault (1991) concludes that the use of vous as a pronominal form of address is still evident in Montreal French, although $t u$ appears to be generally more prevalent due to its use as interrogative suffix, its recurrence in the spontaneous oral production of $t u$ sais (tsé) and other fixed discourse markers, and its use as an indefinite pronoun. She suggests that the considerable increase in the occurrence of $t u$ in uses other than second-person pronominal reference is likely not due to a weakening of the sociostylistic opposition between $t u$ and vous. She attributes the increased use of $t u$ for indefinite reference to a restructuring of clitic subject pronouns. That is, the strong tendency to use on to make first-person plural reference (rather than nous) supports the replacement of $o n$ in its role as indefinite pronoun by another form, namely $t u$ (cf. Ashby, 1992; Laberge \& Sankoff, 1980).

Also in Quebec, Vincent (1993) undertook a large-scale study of the use of second-person pronouns among francophones in the Quebec City area. The sample consisted of over 3000 francophones who were either surveyed via questionnaires or observed. Findings indicated that while older subjects tended to report an almost consistent use of vous with service people, younger subjects' selection between tu and vous was much less consistent. Although the study confirmed young people's preference for $t u$, it also confirmed that as they grow older, they generally use vous more often as they increase contacts with unknown people. Vincent concludes that $t u$ is the more frequently used form of address and is a marker of reciprocity between interlocutors; vous, on the other hand, is reserved for people who are strangers, different (e.g., older), or in higher status positions, and reveals asymmetry between interlocutors (cf. Brown \& Gilman, 1972; Lambert \& Tucker, 1976; Mühlhäusler \& Harré, 1990). ${ }^{9}$

Similarly, from the results of the present study, it may be concluded that singular vous is generally used by adolescents as a marker of formality that reveals some degree of social distance between interlocutors. Unlike the conditional, vous cannot be used among young friends for the sake of politeness; it is thus a formal marker par excellence because it clearly establishes some degree of social distance between interlocutors. Such social distance appears to be a function of the difference in age between interlocutors and their degree of familiarity. That is, social distance increases as age differences increase and, concomitantly, as familiarity decreases. However, formality constraints determined by the characteristics of the interlocutors and their relationship may be overridden by the purpose of the interaction (e.g., complaining about being pushed).

The uniformity of the data elicited in the present study may be best explained in the light of Lambert and Tucker's (1976) observation that $t u$ /vous usage varies in accordance with several factors, including, for example, age, sex, social class, and setting (urban or rural). In the present study, the native speakers constituted a relatively homogeneous group of 13 to 15 -yearold students attending the same school in a Quebec City suburb. Accordingly, the high level of agreement with respect to $t u /$ vous usage within this group should come as no surprise. No differences were found within the sample with respect to gender in either written or oral production; however, this variable had been controlled for insofar as female students were shown slides of females, and male students were shown slides of males (with the exception of the slides depicting teachers and the librarian).

Concerning the oral production results in the present study, it could be argued that the dichotomized structure of the oral measures, involving a formal situation followed by an informal one (or vice versa), may have led native speakers to use language in accordance with an apparent test structure rather than with authentic social situations. Yet students had been informed that there were no "wrong" responses, and the fact that 5 out of 22 native speakers used $t u$ rather than vous to address an unknown adult who was pushing them in line indicates that they did indeed take into account the nature of the speech act. For these five native speakers, the face-threatening act of pushing, as mentioned above, overrode the strong formality constraint established in the other situations.

If it should be the case that some subjects produced language in ways that they believed to be appropriate given the test situation, rather than in ways that they would truly employ in real life situations, then it may nonetheless be concluded that there exists a set of sociolinguis- 
tic rules of which the adolescent native speakers in the sample are clearly aware and that they are able to demonstrate this awareness with a high degree of consensus. Given such awareness, as well as the ability to vary readily the use of second-person pronouns in actual production as elicited by the OP test, these native speakers are in a position to make choices regarding the use of $t u$ and vous in a variety of more authentic contexts, unlike the L2 learners described previously in this article.

\section{PEDAGOGICAL IMPLICATIONS}

With respect to L2 pedagogy, some may suggest that the apparent absence of unequivocal rules of uniform usage precludes the teaching of sociostylistic variation (see, for example, Gardner-Chloros, 1991, regarding the teachability of the $t u$ /vous distinction). However, it may be proposed that the converse in fact holds true. That is, the more language features are distinguished by variability in native-speaker usage, the more they may require explicit attention in the classroom. Although schools systematically favor the normative use of standard language, it remains clear that considerable language variation is indeed normative. In the case of L2 teaching, which generally promotes standard L2 variants, a less static view of language (i.e., one in which language is characterized by considerable sociostylistic variation) is essential and is indeed fundamental to trends in communicative language teaching.

In terms of the specific language features examined and discussed in this article, some simple recommendations may be made. First, with respect to question formation, it would be appropriate for teachers to make their L2 learners of French aware of the aforementioned continuum of formality. At the more formal end of the spectrum, students should be made aware of the usefulness of indirect questions to make polite requests in formal written correspondence. At the colloquial end of the spectrum, L2 learners in a Canadian context should be made aware of the ubiquity of the interrogative suffix $-t u$ as a question marker in informal speech in Quebec French; they should understand, however, that this question marker occurs only in spoken French and generally marks a situation as a familiar one. Between these extremes, yes/ no questions using either est-ce que or simple inversion appear to be used by adolescents in Quebec equally often in oral contexts involving similar levels of formality; however, the occur- rence of these question forms is greater in formal contexts than in informal contexts because the interrogative suffix - $t u$ provides an alternative form in informal contexts. This distribution applies at least to the speech acts of requesting, complaining, and offering assistance.

Second, with regard to the conditional, learners need to be aware of its usefulness for marking a modal value across varying levels of formality. Although research has shown this to be a difficult feature for young L2 learners to acquire productively even after many years of exposure to French in immersion programs (e.g., Harley \& Swain, 1984), teachers should not postpone the teaching of this feature, presuming that the conditional is a sophisticated form that belongs to more formal discourse. Based on the data in this study, the conditional is a useful form that serves in everyday speech among peers to attenuate simple speech acts such as making requests or complaints. Other research has shown the conditional to occur infrequently in classroom discourse and suggests that teachers should contrive contexts that make this feature more salient in the input and obligatory in student output (e.g., Harley et al., 1987; Swain, 1988). Day and Shapson's (1991) experimental study on the teaching of the conditional in Grade 7 FI classrooms includes innovative ways of doing this.

Third, with respect to the use of $t u$ and vous, teachers need to know that the sociostylistic distinction between these pronouns continues to exist in Quebec French, contrary to the impressions described earlier in this article. It would be helpful for teachers to understand some of the reasons, as described by Thibault (1991), that contribute to such impressions: the widespread use of $t u$ as interrogative suffix and as indefinite pronoun, in addition to its frequent occurrence in discourse markers such as $t u$ sais (tse). Teachers need not believe that vous is falling into disuse in Quebec French and need not question its usefulness as a key to successful entry into authentic communication with older native speakers in a variety of contexts, such as the situations used in this study involving unknown adults. However, it may not be necessary for teachers to draw explicit attention to vous as a marker of formality until L2 learners reach adolescence, a time at which they are sorting out sociostylistic variation in L1 in fairly explicit ways as contacts beyond the home and school begin to increase. Finally, because we know from research that this distinction is a difficult one for L2 learners to master in communi- 
catively oriented classroom settings (Allen et al., 1990; Harley et al., 1990; Swain \& Carroll, 1987; Swain \& Lapkin, 1990), it would be best that teachers not confuse the issue by using the collective $t u$, which has been attested in primary classrooms in Quebec (Billey-Lichon, 1992).

Notwithstanding these specific recommendations, the conclusions drawn from the data elicited in the present study must not be construed as sociolinguistic rules to prescribe in absolute terms to L2 learners. Such prescription would fail to take into account the fact that the data are representative of only one specific milieu, and would thereby counter the variable nature of sociolinguistic phenomena. Instead, the recommendations may be used as one set of descriptive data among others in the teaching of sociostylistic variation. Indeed, teaching sociostylistic variation does not entail the conveyance of one set of prescriptive rules but necessitates instead the provision of a variety of descriptive information, involving a wide range of sociostylistic options in various contexts that aim to develop students' awareness of sociostylistic variation and their ability to make appropriate linguistic choices in this respect. Thus, a more general implication for teaching would be that, first, L2 learners need to be made aware that there are indeed sociostylistic choices to be made and, second, that such choices may be made in accordance with the learner's interpretation of the social context. Such interpretation should at the least take account of participant roles, degrees of familiarity and formality, purpose of the interaction, and mode of communication. L2 instruction and communication activities that emphasize in this way the learner's interpretation of social variables would be in keeping with various aspects of the multidimensional L2 curriculum proposed by Stern $(1983,1992)$ and with the basic tenets of communicative language teaching.

\section{ACKNOWLEDGMENTS}

The data analysis phase of this study was supported by financial assistance from the Social Sciences and Humanities Research Council of Canada and from the Fonds pour la Formation des Chercheurs et l'Aide à la Recherche. I would like to thank Birgit Harley, Patsy Lightbown, Leila Ranta, Jacques Rebuffot, and Pierrette Thibault for helpful comments on various versions of this article. I am also grateful to the anonymous $M L J$ reviewers for their insightful comments that helped to produce this final version. I would also like to express my gratitude to the faculty members at the Modern Language Centre of the Ontario Institute for Studies in Education for allowing me to use and adapt the sociolinguistic tests they had developed for the Development of Bilingual Proficiency Project.

\section{NOTES}

${ }^{1}$ Note, however, the emergence in Quebec of a collective $t u$, which is often used to address whole classes of young children in an attempt to implicate each individual child more intimately in the discourse (Billey-Lichon, 1992).

2 Although not further discussed in this paper, it should be mentioned that, in addition to these three features, adolescent native speakers used a variety of politeness expressions in formal letters to attenuate their requests by providing the addressee with the option of either accepting or refusing. For example, of the 38 native speakers using such expressions, 22 used expressions with si (e.g., s'il vous plait, si vous voulez, si vonus le voulez bien, si vous êtes d'accord, si ce n'est pas trop demander). In addition, many subjects also used a variety of simple yet polite closings that served as expressions of gratitude in formal letters. Whereas formal letters in French usually conclude with formulaic closings such as, "Veuillez croire, Monsieur, à l'expression de mes meilleurs sentiments," none of the adolescent native speakers used such elaborate phrases; instead, they more simply expressed their gratitude. Of the 53 native speakers who concluded their letter with a polite closing, $39(73.6 \%)$ used one of the following: Merci $(n=13)$, Merci de votre compréhension $(n=8)$, Merci d'avance $(n=8)$, Merci à l'avance $(n=4)$, Je vous remercie à l'avance $(n=4)$, Je vous remercie d'avance $(n=2)$.

${ }^{3}$ English translations are not consistently provided throughout this article because the contrasts being highlighted in French are often formal rather than semantic and do not necessarily have English equivalents (e.g., est-ce que questions vs. inverted questions, nominal vs. pronominal inversion, $t u$ vs. singular vous); such formal contrasts are explained throughout with the use of appropriate metalanguage. The tasks that subjects were asked to perform (i.e., making various requests, complaints, and offers) generally constrained the range of possible meanings; accordingly, the task descriptions point to the meaning of most instances of French.

4 Because "silteplant" was not broken down into its constituent parts, it seems that this native speaker was unaware of the link between the infix te and the second-person pronoun $t u$. In Canadian French, sil vous plait has become a neutral term in both formal and informal situations. Sil te plaît is rarely used and has thus become a marked form (Raymond Mougeon, personal communication). Due to its markedness, this native speaker seems to have understood this expression as a formal variant. The fact that s'il vous plait is a neutral form used invariably in formal and infor- 
mal contexts was clearly evidenced by the nativespeaker data in both written and oral production.

5 See Picard (1991) and Harris (1978, p. 33) for accounts of this feature's evolution in French. It developed through the liaison of a verb-final consonant and $i l$ with the final / $/$ / deleted in inverted question forms, as illustrated in the following sequences:

Vient-il? $\rightarrow$ Vient-i? $\rightarrow$ Jean vient $-i$ ? $\rightarrow I$ vient $-i$ ? $\rightarrow I$ vient ti?

Mange-t-il? $\rightarrow$ Mange-t-i? $\rightarrow$ Jean mange-t-i? $\rightarrow$ I mange$t i$ ?

Thus, the postverbal pronoun became redundant and lost its semantic identity to - $t$, an element which came to be identified with question formation. The use of $-t i$ as question marker then spread to other persons through a series of phonological, syntactic, and analogical processes described by Picard. He explains that $-t i$ is now almost nonexistent in Continental French (yet, according to Gadet, 1989, p. 141, it may still be heard in regions of Brittany and Normandy), but that in Canadian French a postverbal interrogative particle is still common in speech but has been replaced by -tu due to the latter's greater semantic transparency (see also Grevisse, 1986, §387). Picard argues that this particle should be classified grammatically as an interrogative suffix.

${ }^{6}$ In giving directions, regardless of formality, subjects generally used present indicative forms ("Vous tournez à gauche . . ." "Tu tournes à gauche . . ."), occasionally used the immediate future ("Vous allez tourner $\grave{a}$ droite . .."/"Tu vas tourner $\dot{a}$ droite . . ."), and infrequently used imperative verb forms ("Continuez tout droit . . .") "Continue tout droit . . .").

7 Lightbown's (1980, pp. 168-169) account of question forms indicated that the input provided by an adult native speaker of Quebec French to two child learners of French L2 rarely contained inverted yes/ no questions. Similarly, Lightbown and d'Anglejan (1985) report on input provided in a Montreal context by a native speaker, which again confirmed "the very rare occurrence of inverted question forms in the input addressed to language learners" (p. 419).

8 In his discussion of markers of modality in French, Harris (1978) inlcudes vouloir and savoir (in addition to pouvoir) as verbs that function at times as modal auxiliaries. In the present corpus, however, savoir was not used modally.

9 In their seminal study of the development of $t u /$ vous systems in western European languages, Brown and Gilman (1960/1972) described a shift from a "power semantic," characterized by an asymmetrical pattern of second-person pronominal usage (i.e,, a nonreciprocal use of $t u$ and vous), to a "solidarity semantic," characterized by a symmetrical pattern of address (i.e., reciprocal use of either $t u$ or vous). They argued that the need to express differences in status through pronoun usage had yielded to the expression of solidarity associated with the emergence of egalitarian ideology and social mobility. Lambert and Tucker (1976), however, proposed that the power-solidarity distinction was too simple to account for the sociopsychological significance of pronominal address patterns, and argued instead that the choice of second-person pronouns reveals much more about interpersonal relationships than difference in status or degree of solidarity. Similarly, and more recently, Mühlhäusler and Harré (1990, p. 132) agreed that neither direction of power nor degree of solidarity is sufficient to explain choice of second-person pronouns. They refined the powersolidarity distinction (in which they included rank, status, office, and generation) by adding degrees of formality and informality, public and private discourse, intimacy and social distance, and emotional excitement.

\section{REFERENCES}

Allen, P., Cummins, J., Mougeon, R., \& Swain, M. (1983). The development of bilingual proficiency: Second year report and appendices. Toronto, Canada: Modern Language Centre, Ontario Institute for Studies in Education.

Allen, P., Swain, M., Harley, B., \& Cummins, J. (1990). Aspects of classroom treatment: Toward a more comprehensive view of second language education. In B. Harley, P. Allen, J. Cummins, \& M. Swain (Eds.), The development of second language proficiency (pp. 57-81). Cambridge, England: Cambridge University Press.

Ashby, W. (1992). The variable use of on versus $t u /$ vous for indefinite reference in spoken French. Journal of French Language Studies, 2, 135-157.

Bachman, L. (1990). Fundamental considerations in language testing. Oxford, England: Oxford University Press.

Barbarie, Y. (1982). Analyse sociolinguistique de la syntaxe de l'interrogation en français québécois. Revue québécoise de linguistique, 12, 145-167.

Battye, A., \& Hintze, M. -A. (1992). The French language today. London: Routledge.

Billey-Lichon, E. (1992, November 8). Une langue française "made in Québec." La Presse, p. B2.

Brown, P., \& Levinson, S. (1987). Politeness: Some universals in language use. Cambridge, England: Cambridge University Press.

Brown, R., \& Gilman, A. (1960/1972). The pronouns of power and solidarity. In J. Fishman (Ed.), Readings in the sociology of language. The Hague: Mouton.

Canale, M. (1983). From communicative competence to communicative language pedagogy. In J. Richards \& R. Schmidt (Eds.), Language and communication (pp. 2-27). London: Longman.

Canale, M., \& Swain, M. (1980). Theoretical bases of communcative approaches to second language teaching and testing. Applied Linguistics, 1, 1-47.

Coveney, A. (1990). Variation in interrogatives in spoken French: A preliminary report. In J. Green 
\& W. Ayres-Bennett (Eds.), Variation and change in French (pp. 116-133). London: Routledge.

Day, E., \& Shapson, S. (1991). Integrating formal and functional approaches to language teaching in French immersion: An experimental study. Language Learning, 41, 25-58.

Di Sciullo, A. -M., \& St-Pierre, M. (1982). Les actes de requête dans les énoncés de forme impérative et interrogative en français de Montréal. In C. Lefebvre (Ed.), La syntaxe comparée de français standard et populaire : approches formelle et fonctionnelle, Vol. 2 (pp. 153-175). Quebec City, Canada: Éditeur officiel du Québec.

Doran, M., Drapeau, L., \& Lefebvre, C. (1982). Le projet Centre-sud : corpus et méthodologie. In C. Lefebvre (Ed.), La syntaxe comparée de français standard et populaire: approches formelle et fonctionnelle, Vol. 2 (pp. 401-422). Quebec City, Canada: Éditeur officiel du Québec.

Gadet, F. (1989). Le francais ordinaire. Paris: Armand Colin.

Gardner-Chloros, P. (1991). Ni tu ni vous : principes et paradoxes dans l'emploi des pronoms d'allocution en français contemporain. Journal of French Language Studies, 1, 139-155.

Grevisse, M. (1986). Le bon usage. Paris-Gembloux: Duculot.

Gumperz, J. (1972). Sociolinguistics and communication in small groups. In J. Pride \& J. Holmes (Eds.), Sociolinguistics: Selected readings. Harmondsworthe, England: Penguin.

Harley, B. (1986). Age in second language acquisition. Clevedon, England: Multilingual Matters.

Harley, B. (1989). Functional grammar in French immersion: A classroom experiment. Applied Linguistics, 10, 331-359.

Harley, B., \& Swain, M. (1984). The interlanguage of immersion students and its implications for second language teaching. In A. Davies, C. Criper, \& A. Howatt (Eds.), Interlanguage (pp. 291-311). Edinburgh, Scotland: Edinburgh University Press.

Harley, B., Allen, P., Cummins, J., \& Swain, M. (1987). Development of bilingual proficiency. Final report. Volume II: Classroom treatment. Toronto, Canada: Modern Language Centre, Ontario Institute for Studies in Education.

Harley, B., Cummins, J., Swain, M., \& Allen, P. (1990). The nature of language proficiency. In B. Harley, P. Allen, J. Cummins, \& M. Swain (Eds.), The development of secomd language proficiency (pp. 7-25). Cambridge, England: Cambridge University Press.

Harris, M. (1978). The evolution of French syntax: $A$ comparative approach. London: Longman.

Hatch, E., \& Lazaraton, A. (1991). The research manual: Design and statistics for Applied Linguistics. New York: Newbury House.

Hymes, D. (1971). Competence and performance in linguistic theory. In R. Huxley \& E. Ingram (Eds.), Language acquisition: Models and methods (pp. 3-28). London: Academic Press.
Laberge, S., \& Sankoff, G. (1980). Anything you can do. In G. Sankoff (Ed.), The social life of language (pp. 271-293). Philadelphia: University of Pennsylvania Press.

Lakoff, R. (1977). What you can do with words: Politeness, pragmatics, and performatives. In A. Rogers, B. Wall, \& J. Murphy (Eds.), Proceedings of the Texas Conference on Performatives, Presuppositions, and Implicatures (pp. 79-105). Arlington, VA: Center for Applied Linguistics.

Lambert, W., \& Tucker, R. (1976). Tu, vous, Usted. A social-psychological study of address patterns. Rowley, MA: Newbury House.

Lightbown, P. (1980). The acquisition and use of questions by French L2 learners. In S. W. Felix (Ed.), Second language development: Trends and issues (pp. 151-175). Tübingen, Germany: Gunter Narr.

Lightbown, P., \& d'Anglejan, A. (1985). Some input considerations for word order in French $L 1$ and L2 acquisition. In S. Gass \& C. Madden (Eds.), Input in second language acquisition (pp. 415-430). Boston: Heinle.

Lyster, R. (1993). The effect of functional-analytic teaching on aspects of sociolinguistic competence: $A$ study in French immersion classrooms at the Grade 8 level. Unpublished doctoral dissertation, University of Toronto, Toronto, Ontario, Canada.

Lyster, R. (1994). The effect of functional-analytic teaching on French immersion students' sociolinguistic competence. Applied Linguistics, 15, 263-287.

McCool, G. (1994). Teaching the formation of questions: Lessons from New French. Modern Language Journal, 78, 56-60.

Mühlhãusler, P., \& Harré, R. (1990). Pronouns and people: The linguistic construction of social and personal identity. Oxford, England: Basil Blackwell.

Picard, M. (1991). Clitics, affixes, and the evolution of the question marker "tu" in Canadian French. Journal of French Language Studies, 1, 179-187.

Sankoff, G., \& Thibault, P. (1995). What they didn't learn at school: Vernacular Québécois features in anglophone French. Paper presented at the Second Language Research Forum (SLRF), Cornell University, Ithaca, NY.

Seutin, E. (1975). Description grammaticale du parler de l'lle-aux-Coudres. Montreal, Canada: Presses de l'Université de Montréal.

Stern, H. H. (1983). Toward a multidimensional foreign language curriculum. In R. G. Mead (Ed.), Foreign languages: Key links in the chain of learning (pp. 120-146). Middlebury, VT: Northeast Conference.

Stern, H. H. (1992). Issues and options in language teaching. P. Allen and B. Harley (Eds.). Oxford, England: Oxford University Press.

Swain, M. (1988). Manipulating and complementing content teaching to maximize second language learning. TESL Canada Journal, 6, 68-83.

Swain, M., \& Carroll, S. (1987). The immersion obser- 
vation study. In B. Harley, P. Allen, J. Cummins, \& M. Swain (Eds.), Development of bilingual proficiency. Final report. Volume II: Classroom treatment. Toronto, Canada: Modern Language Centre, Ontario Institute for Studies in Education

Swain, M., \& Lapkin, S. (1990). Aspects of the sociolinguistic performance of early and late French immersion students. In R. Scarcella, E. Andersen, \& S. Krashen (Eds.), Developing communicative competence in a second language (pp. 41-54). New York: Newbury House.

Tarone, E., \& Swain, M. (1995). A sociolinguistic per- spective on second language use in immersion classrooms. Modern Language Journal, 79, 166178.

Thibault, P. (1991). La langue en mouvement : simplification, régularisation, restructuration. LINX (Linguistique - Paris X, Nanterre), 25, 9-92.

Tremblay, M. (1968/1972). Les Belles-Soeurs. Ottawa, Canada: Leméac.

Vincent, D. (1993, September 2). Entre tu et vous. Au fil des événements [weekly newspaper, Laval University], pp. 7, 10.

\section{AAUSC Announces 1997 Annual Volume on Technology}

THE AMERICAN ASSOCIATION OF UNIVERSITY SUPERVISORS, COORDINATORS, AND DIrectors of Foreign Language Programs is pleased to announce its 1997 annual volume and to invite you to submit articles for consideration.

New Ways of Learning and Teaching: Focus on Technology and Foreign Language Education

Edited by Judith Muyskens, University of Cincinnati

The volume will focus on technology and its effect on our academic endeavor of teaching and learning foreign languages. It will strive to answer some of the questions posed by James Noblitt in "The Electronic Language Learning Environment" of the 1995 AAUSC volume. In particular, the volume hopes to attract articles that respond to the following, and related, questions: What is the state of electronics and technology in higher education and the present status of the foreign language profession within that context? What is the future of foreign language instruction as we know it in light of the information revolution? Will we see our content emphasis broaden or shift? Will we raise our expectations for student achievement in skill areas? How effective will foreign language learning be using the new technologies? Will the foreign language profession be prepared to meet the demands of students who are sophisticated in their experience with technology? Who will prepare the new multimedia materials? How will we train professors for the future in light of the information revolution and technological advances? What effects will the new technologies have on TA training programs and multisection courses?

Papers may deal with policy issues, survey research, and empirical studies. Articles that provide only program and materials descriptions will not be accepted, but authors are encouraged to use model programs as examples to ground papers that address broader issues or concerns.

Submission deadline: November 1, 1996.

Judith Muyskens

Department of Romance Languages and Literatures

P. O. Box 210377

University of Cincinnati

Cincinnati, OH 45221-0377

judith.muyskens@uc.edu

513-556-1950 